\title{
DISTRIBUTION OF HEPATITIS B INFECTED POPULATION BY SEX AND AGE GROUPS IN DISTRICT D.I.KHAN, PAKISTAN
}

\author{
Imran Ullah', (D) Nisar Khan², (DFarmanullah Shah³, (DEjaz Ahmad4, (DAsif Saeed ${ }^{4}$ \\ ${ }^{1}$ District Health Office, D.I.Khan, Departments of ${ }^{2}$ Medicine $\&{ }^{3}$ Gastroenterology, MMMT Hospital, D.I.Khan, \\ ${ }^{4}$ Department of Medicine, Lady Reading Hospital, Peshawar, Pakistan
}

\begin{abstract}
Background: Significant morbidity and mortality is caused by untreated hepatitis B virus infection through cirrhosis and hepatocellular carcinoma. The objectives of our study were to determine distribution of hepatitis B infected population by sex and age groups in District D.I.Khan, Pakistan.

Materials \& Methods: This cross-sectional study was done at District Health Office, D.I.Khan, Pakistan from January 30, 2021 to February 15, 2021. Data was collected for period from March 14, 2013 to January 28, 2021 for 2368 hepatitis B infected cases from population at risk consecutively. Sex and age groups were demographic variables. Data type was nominal for sex and ordinal for age groups. Distribution was analyzed by count, percentage and confidence intervals for proportion for population. Hypotheses for distribution were substantiated by chi-square goodness-of-fit test.

Results: Out of 2368 hepatitis B infected population, 1670 (70.52\%) were men \& 698(29.48\%) women, and 562 (23.73\%) were in age group 0-20 years, $1266(53.46 \%)$ in 21-40 years, $462(19.51 \%)$ in $41-60$ years \&78 (3.30\%) in $>60$ years. Our distribution by sex $(p<.00001)$ and age groups $(p<.00001)$ were different than expected respectively.
\end{abstract}

Conclusion: In our study, hepatitis B infection was more common in men than women and most common in age group 21-40 years, followed by 0-20 years, 41-60 years and $>60$ years. Our observed prevalence of hepatitis B infection in men was higher than expected \& in women it was lower than expected. Our observed prevalence in the four age groups was not similar to expected.

KEY WORDS: Distribution; Population; Hepatitis B; Hepatitis B Virus; Sex; Age Groups; Chi-square Goodness of fit Test; Pakistan.

Cite as: Ullah I, Khan N, Shah F, Ahmad E, Saeed A. Distribution of hepatitis B infected population by sex and age groups in District D.I.Khan, Pakistan. Gomal J Med Sci 2021 Apr-Jun; 19(2):47-52. https://doi.org/10.46903/ gjms/19.02.1017

\section{INTRODUCTION}

1.1 Background: Globally hepatitis B virus infects about 296 million people accounting for $3.8 \%$ prevalence in 2019. In 2019, about 1.5 million new infections and 0.82 million mortality were caused by hepatitis $B$ virus infection globally. About 6 million $(0.9 \%)$ children under 5 year of age are infected with HBV. ${ }^{1}$

\section{Corresponding Author:}

Dr. Imran Ullah

District Health Office

D.I.Khan, Pakistan

E-mail: drimranullah89@gmail.com

$\begin{array}{ll}\text { Date Submitted: } & 16-02-2021 \\ \text { Date Revised: } & 23-03-2021 \\ \text { Date Accepted: } & 30-03-2021\end{array}$

If not treated, hepatitis $B$ and hepatitis $C$ virus infections may cause cirrhosis\& hepatocellular carcinoma, causing $96 \%$ of the deaths due to viral hepatitis. In 2015, 2.7 million HIV infected patients also had HBV infection. Peoples in the European and Eastern Mediterranean regions are more infected. ${ }^{2}$ In 2019, in Eastern Mediterranean Region, the prevalence of hepatitis B infections was $2.5 \%$, estimating about 18.2 million infections. ${ }^{1}$

Badawi, et al. ${ }^{3}$ from Khartoum state of Sudan for the period from Oct. 2011 to Jan. 2017 distributed 2109 PCR detected HBV infection as $77.81 \%(1641 * 100 / 2109=77.81)$ men $\& 22.19 \%$ $(468 * 100 / 2109=22.19)$ women, and $6.16 \%$ $(130 * 100 / 2109=6.16)$ in age group $<20$ years, $64.06 \%$ $(1351 * 100 / 2109=64.06)$ in $20-39$ years, $24.56 \%$ $(518 * 100 / 2109=24.56)$ in $40-59$ years, $4.93 \%$ $(104 * 100 / 2109=4.93)$ in $60-79$ years $\& 0.29 \%$ $(6 * 100 / 2109=0.29)$ in $>80$ years. 
Soliman, et al. ${ }^{4}$ from Luxor, Egypt during Jun. 2016May 2017 distributed 2947 HBsAg positive patients as $67.25 \%(1982 * 100 / 2947=67.25)$ men and $32.75 \%$ $(965 * 100 / 2947=32.75)$ women.

Tao, et al. ${ }^{5}$ from Shenzhen, China for the period from 26 August 2015 to 11 Sep 2018 distributed 19922PCR detected HBV infections as $58.53 \%(11661 * 100 / 19922=58.53)$ men $\& 41.47 \%$ $(8261 * 100 / 19922=41.47)$ women, and $0.27 \%$ $(54 * 100 / 19922=0.27)$ in age group $<1$ year, $0.09 \%(18 * 100 / 19922=0.09)$ in $1-5$ years, $1.56 \%$ $(310 * 100 / 19922=1.56)$ in $6-19$ years, $77.82 \%$ $(15503 * 100 / 19922=77.82)$ in $20-49$ years $\& 20.26 \%$ $\left(4037^{\star} 100 / 19922=20.26\right)$ in $\geq 50$ years.

Mousawea, et al. ${ }^{6}$ from Kabul, Afghanistan for the period from Apr. 2014 to Aug. 2017 distributed $2430 \mathrm{HBsAg}$ positive patients as $79.01 \%(1920 * 100 / 2430=79.01)$ men and $20.99 \%(510 * 100 / 2430=20.99)$ women, and $8.68 \%(211 * 100 / 2430=8.68)$ in age group $1-20$ years, $49.79 \%(1210 * 100 / 2430=49.79)$ in $21-40$ years, $30.91 \%(751 * 100 / 2430=30.91)$ in $41-60$ years \& $10.62 \%(258 * 100 / 2430=10.62)$ in $\geq 61$ years. Khan, et al. ${ }^{7}$ in Lahore, Punjab, Pakistan during 2008-2010 distributed 3143 PCR detected HBV infections as $68.15 \%(2142 * 100 / 3143=68.15)$ men and $31.85 \%(1001 * 100 / 3143=31.85)$ women.

Ullah, et al. ${ }^{8}$ in Peshawar, Pakistan during Nov. 2015-Apr. 2016 distributed $65 \mathrm{HBsAg}$ positive patients as $38.46 \%(25 * 100 / 65=38.46)$ men $\& 61.54 \%(40 * 100 / 65=61.54)$ women, and $1.61 \%$ $(1 * 100 / 62=1.61)$ in age group $1-20$ years, $24.19 \%(15 * 100 / 62=24.19)$ in $21-40$ years, $50 \%(31 * 100 / 62=50)$ in $41-60$ years $\& 24.19 \%$ $\left(15^{*} 100 / 62=24.19\right)$ in $61-80$ years.

Khan, et al. ${ }^{9}$ from Mardan, Pakistan during Jan. 2014-Jan. 2015 distributed 260 PCR detected HBV infections as $56.92 \%(148 * 100 / 260=56.92)$ men \& $43.08 \%(112 * 100 / 260=43.08 \%)$ women, and $11.54 \%(30 * 100 / 260=11.54)$ in age group $1-20$ years, $60.38 \%\left(157^{*} 100 / 2109=60.38\right)$ in $21-40$ years, $19.62 \%(51 * 100 / 260=19.62)$ in $41-60$ years $\& 8.46 \%$ $(22 * 100 / 260=8.46)$ in $>60$ years.

Ullah, et al. ${ }^{10}$ from Mardan, Pakistan during 20172020 years distributed 276 PCR detected HBV infections as $61.23 \%(169 * 100 / 276=61.23)$ men \& $38.77 \%(107 * 100 / 276=38.77)$ women and $3.62 \%$ $(10 * 100 / 276=3.62)$ in age groups $10-20$ years, $78.26 \%(216 * 100 / 276=78.26)$ in $21-40$ years, $16.67 \%$ $(46 * 100 / 276=16.67)$ in $41-60$ years $\& 1.45 \%$ $(4 * 100 / 276=1.45)$ in $\geq 61$ years.

2 Research Problems, Knowledge Gaps, Research Questions \& Rationale: Lack of information regarding the distribution of hepatitis $B$ infected population by sex and age groups in District D.I.Khan were our two research problems. Pertinent data in regard to these research problems could not be recovered by online search, showing two gaps in our existing knowledge. How will be the hepatitis B infected population of District D.I.Khan distributed by sex and age groups will be our two research questions. To answer these two questions will be the justification for our project.

\subsection{Research Objectives (ROs)}

RO 1: To find out the distribution of hepatitis $B$ infected population by sex in District D.I.Khan.

RO 2: To find out the distribution of hepatitis $B$ infected population by age groups in District D.I.Khan.

\subsection{Research (Null) Hypotheses}

$\mathbf{H}_{01}$ : The observed and expected distribution of hepatitis $B$ infected population by sex was not different in District D.I.Khan.

$\mathbf{H}_{02}$ : The observed and expected distribution of hepatitis $B$ infected population by age groups was not different in District D.I.Khan.

\section{MATERIALS AND METHODS}

2.1 Study Design, Settings \& Duration: This descriptive study was executed at District Health Office, D.I.Khan, Pakistan from 30-1-2021 to15-2-2021.

2.2 Population, Sample Size \& Technique and Sample Selection: District D.I.Khan population was 852,995 in 1998 Census. It was assumed to be around 1400,000 in 2013. Sample size was calculated as 2368 assuming expected prevalence rate of $\mathrm{HBV}$ as $2.5^{1}{ }^{1}$ in our population with margin of error $0.6283 \%$ and $95 \%$ CL. ${ }^{11}$ Consecutive sampling method was employed. All hepatitis B infected patients were included. Those with incomplete data were not eligible.

2.3 Conduct of Procedure: Detailed information was taken regarding clinical features, risk factors, co-morbidities and indications for treatment. Necessary investigations like HBsAg by ICT and/ or ELISA were done. Polymerase chain reaction (PCR) was done to confirm infection and quantitate viral load. After confirming diagnosis and indications for treatment, patients were started on recommended antiviral treatment.

2.4 Data Collection Plan: Sex and age groups were demographic variables. Sex was nominal while age group was an ordinal variable.

\subsection{Data Analysis Plan}

2.5.1 Descriptive Statistics and Estimation of $\mathrm{Pa}$ rameters: Distribution for sex and age groups for the sample was described by count and percentage. Estimated distribution for the population were estimated as $\mathrm{Cl}$ at $95 \% \mathrm{CL}$ by normal approximation method. ${ }^{12}$

2.5.2 Hypotheses Testing: Two hypotheses were verified using chi-square goodness of fit test at alpha .05, showing observed \& expected counts, test statistics, degree of freedom and significance $\left(\mathrm{H}_{01}\right.$ \& $\left.\mathrm{H}_{02}\right) \cdot{ }^{13-15}$ 


\section{RESULTS}

\subsection{Descriptive Statistics \& Estimation of Param- eters}

3.1.1 Distribution of hepatitis B infected population by sex and age groups

The distribution of 2368 hepatitis B infected population by sex and age groups is seen in Table 3.1.1. Based on confidence intervals, the prevalence is more common in men $70.52 \%$ than women $29.48 \%$ and most common in age group 21-40 years (53.46\%), followed by 0-20 years (23.73\%), 41-60 years $(19.51 \%) \&>60$ years $(3.30 \%)$.

\subsection{Hypotheses Testing}

3.2.1 Observed vs. expected distribution of hepatitis $B$ infected population by sex $\left(H_{01}\right)$ : Our observed counts of 2368 patients for men vs. women were 1670:698 against expected counts of 148:112 for 260 patients as shown by Khan, et al. ${ }^{9}$ Due to differences in sizes of samples, comparison could not be logical. Therefore the expected counts were adjusted to our sample size of 2368, giving us adjusted expected counts of 1348:1020, with no change in adjusted expected percentages. (Table 3.2.1.1)

Test of significance gave us $p$-value $<.00001$, rejecting $\mathrm{H}_{01}$, which shows that the observed prevalence of hepatitis $B$ infection in men $70.52 \%$ was higher than its expected (adjusted) prevalence for men $56.92 \%$ \& in women $29.48 \%$ it was lower than its expected (adjusted) prevalence for women $43.08 \%$ as shown by Khan, et al. ${ }^{9}$ (Table 3.2.1.2)

Table 3.1.1: Distribution of hepatitis B infected population by sex and age groups in District D. I. Khan, Pakistan $(\mathbf{n}=2368)$

\begin{tabular}{|l|l|c|c|c|c|}
\hline \multirow{2}{*}{ Variables } & \multirow{2}{*}{ Attributes } & \multicolumn{3}{c|}{ Sample statistics } & \multicolumn{2}{|c|}{$95 \%$ Cl for proportion } \\
\cline { 3 - 6 } & & Count & Percentage & Lower & \multicolumn{1}{c|}{ Upper } \\
\hline \multirow{3}{*}{ Sex } & Men & 1670 & $1670 * 100 / 2368=70.52 \%$ & 68.65 & 72.32 \\
\cline { 2 - 6 } & Women & 698 & $698 * 100 / 2368=29.48 \%$ & 27.68 & 31.35 \\
\hline \multirow{4}{*}{$\begin{array}{l}\text { Age groups } \\
\text { (years) }\end{array}$} & $0-20$ & 562 & $562 * 100 / 2368=23.73 \%$ & 22.06 & 25.49 \\
\cline { 2 - 6 } & $21-40$ & 1266 & $1266 * 100 / 2368=53.46 \%$ & 51.45 & 55.46 \\
\cline { 2 - 6 } & $41-60$ & 462 & $462 * 100 / 2368=19.51 \%$ & 17.96 & 21.15 \\
\cline { 2 - 6 } & $>60$ & 78 & $78 * 100 / 2368=03.30 \%$ & 2.65 & 4.10 \\
\hline Total & 2368 & $2368 * 100 / 2368=100 \%$ & \multicolumn{2}{|c|}{ Population parameters } \\
\hline
\end{tabular}

Table 3.2.1.1: Observed, expected and adjusted expected counts and percentages for distribution of hepatitis $B$ infected population by sex in District D.I.Khan, Pakistan $(n=2368)$

\begin{tabular}{|c|c|c|c|c|c|c|}
\hline Sex & $\begin{array}{l}\text { Observed } \\
\text { counts }\end{array}$ & Observed \%ages & $\begin{array}{l}\text { Expected } \\
\text { counts }\end{array}$ & $\begin{array}{l}\text { Expected } \\
\text { \%ages }\end{array}$ & $\begin{array}{l}\text { Adjusted expected } \\
\text { counts }\end{array}$ & $\begin{array}{l}\text { Adjusted ex- } \\
\text { pected \% }\end{array}$ \\
\hline Men & 1670 & $\begin{array}{c}1670 * 100 / 2368 \\
=70.52 \%\end{array}$ & 148 & $\begin{array}{c}148 * 100 / 260 \\
=56.92 \%\end{array}$ & $\begin{array}{c}148 * 2368 / 260 \\
=1348\end{array}$ & $\begin{array}{c}1348 * 100 / 2368 \\
=56.92 \%\end{array}$ \\
\hline Women & 698 & $\begin{array}{c}698 * 100 / 2368 \\
\quad=29.48 \%\end{array}$ & 112 & $\begin{array}{c}112 * 100 / 260 \\
=43.08 \%\end{array}$ & $\begin{array}{c}112 * 2368 / 260 \\
=1020\end{array}$ & $\begin{array}{c}1020 * 100 / 2368 \\
=43.08 \%\end{array}$ \\
\hline Total & 2368 & $100 \%$ & 260 & $100 \%$ & 2368 & $100 \%$ \\
\hline
\end{tabular}

Table 3.2.1.2: Observed vs. expected distribution of hepatitis B infected population by sex in District D.I. Khan, Pakistan $(n=2368)$

\begin{tabular}{|l|c|c|c|c|c|c|c|c|}
\hline Sex & $\mathrm{O}$ & $\mathrm{E}$ & $\mathrm{O}-\mathrm{E}$ & $(\mathrm{O}-\mathrm{E})^{2}$ & $\mathrm{X}^{2}$ & $\sum \mathrm{X}^{2}$ & d.f. & $\mathrm{p}$-value \\
\hline Men & 1670 & 1348 & 322 & 103684 & 76.92 & 178.57 & 1 & $<.00001$ \\
\hline Women & 698 & 1020 & -322 & 103684 & 101.65 & \multicolumn{2}{|c|}{$\mathrm{H}_{01}$ rejected at alpha .05} \\
\hline Total & 2368 & 2368 & 00 & \multicolumn{7}{|c|}{$\chi^{2}$ goodness-of-fit test with Yates continuity correction } \\
\hline
\end{tabular}

$\mathrm{O}=$ Observed count, $\mathrm{E}=$ Expected count, $\mathrm{X}^{2}=$ Chi-square statistics, d.f. $=$ degree of freedom 
Imran Ullah, et al.

Table 3.2.2.1: Observed, expected and adjusted expected counts and percentages for distribution of hepatitis B infected population by age groups in District D.I.Khan, Pakistan $(n=2368)$

\begin{tabular}{|l|l|c|c|c|c|c|}
\hline $\begin{array}{l}\text { Age groups } \\
\text { (years) }\end{array}$ & $\begin{array}{l}\text { Observed } \\
\text { counts }\end{array}$ & $\begin{array}{c}\text { Observed per- } \\
\text { centages }\end{array}$ & $\begin{array}{c}\text { Expected } \\
\text { counts }\end{array}$ & Expected \%ages & $\begin{array}{c}\text { Adjusted ex- } \\
\text { pected counts }\end{array}$ & $\begin{array}{c}\text { Adjusted expect- } \\
\text { ed \% }\end{array}$ \\
\hline $0-20$ & 562 & $\begin{array}{c}562 * 100 / 2368 \\
=23.73 \%\end{array}$ & 30 & $\begin{array}{c}30 \star 100 / 260 \\
=11.54 \%\end{array}$ & $\begin{array}{c}30 \star 2368 / 260 \\
=273.23\end{array}$ & $\begin{array}{c}273.23 * 100 / 2368 \\
=11.54 \%\end{array}$ \\
\hline $21-40$ & 1266 & $\begin{array}{c}1266^{\star} 100 / 2368 \\
=53.46 \%\end{array}$ & 157 & $\begin{array}{c}157^{*} 100 / 260 \\
=60.38 \%\end{array}$ & $\begin{array}{c}157 \star 2368 / 260 \\
=1429.91\end{array}$ & $\begin{array}{c}1429.91 * 100 / 2368 \\
=60.38 \%\end{array}$ \\
\hline $41-60$ & 462 & $\begin{array}{c}462 * 100 / 2368 \\
=19.51 \%\end{array}$ & 51 & $\begin{array}{c}51 * 100 / 260 \\
=19.62 \%\end{array}$ & $\begin{array}{c}51^{\star} 2368 / 260 \\
=464.49\end{array}$ & $\begin{array}{c}464.49 * 100 / 2368 \\
=19.62 \%\end{array}$ \\
\hline$>60$ & 78 & $\begin{array}{c}78^{*} 100 / 2368 \\
=3.30 \%\end{array}$ & 22 & $\begin{array}{c}22 * 100 / 260 \\
=08.46 \%\end{array}$ & $\begin{array}{c}22 * 2368 / 260 \\
=200.37\end{array}$ & $\begin{array}{c}200.37 * 100 / 2368 \\
=08.46 \%\end{array}$ \\
\hline Total & 2368 & $100 \%$ & 260 & $100 \%$ & 2368 & $100 \%$ \\
\hline
\end{tabular}

Table 3.2.2.2: Observed vs. expected distribution of hepatitis $B$ infected population by age groups in District D.I.Khan, Pakistan $(n=2368)$

\begin{tabular}{|c|c|c|c|c|c|c|c|c|}
\hline $\begin{array}{l}\text { Age groups } \\
\text { (years) }\end{array}$ & $\mathrm{O}$ & $E$ & O-E & $(\mathrm{O}-\mathrm{E}) 2$ & $x^{2}$ & $\sum x^{2}$ & d.f. & $p$-value \\
\hline $0-20$ & 562 & 273 & 289 & 83521 & 305.94 & \multirow{3}{*}{399.19} & \multirow{3}{*}{3} & \multirow{3}{*}{$<.00001$} \\
\hline $21-40$ & 1266 & 1430 & -164 & 26896 & 18.81 & & & \\
\hline $41-60$ & 462 & 465 & -3.00 & 9 & 0.02 & & & \\
\hline$>60$ & 78 & 200 & -122 & 14884 & 74.42 & \multicolumn{3}{|c|}{$\mathrm{H}_{02}$ rejected at alpha .05} \\
\hline Total & 2368 & 2368 & 00 & \multicolumn{5}{|c|}{$\chi^{2}$ goodness-of-fit test with Yates continuity correction } \\
\hline
\end{tabular}

$\mathrm{O}=$ Observed count, $\mathrm{E}=$ Expected count, $\mathrm{X}_{2}=$ Chi-square statistics, d.f. $=$ degree of freedom

3.2.2 Observed vs. expected distribution of hepatitis $B$ infected population by age groups $\left(\mathrm{H}_{02}\right)$ : Our observed counts for 2368 patients for four age groups (0-20:21-40:41-60:>60years) were 562:1266:462:78 against expected counts for 260 patients as 30:157:51:22 as shown by Khan, et al. ${ }^{9}$ Due to differences in sizes of samples, comparison could not be logical. Therefore the expected counts were adjusted to our sample size of 2368, giving us adjusted expected counts of 273.23:1429.91:464.49:200.37, with no change in adjusted expected percentages. (Table 3.2.2.1)

Test of significance gave us $p$-value $<.00001$, rejecting $\mathrm{H}_{01}$, which shows that observed prevalence of hepatitis $B$ infection in four age groups is not similar to its expected prevalence for four age groups from a study by Khan, et al. ${ }^{9}$ (Table 3.2.2.2)

\section{DISCUSSION}

4.1 Distribution of hepatitis $B$ infected population by sex $\left(\mathrm{H}_{01}\right)$ : The prevalence of hepatitis $B$ infected population was higher in men $70.52 \%(95 \% \mathrm{Cl} 68.65-$ 72.32) than women $29.48 \%(95 \% \mathrm{Cl} 27.68-31.35)$ in our population. (Table 3.1.1)
Similar to our findings, higher prevalence in men than women were reported by Ullah , et al. ${ }^{10}(61.23 \%$ vs. $38.77 \%$ ), Khan, et al. ${ }^{9}$ from Mardan, Pakistan (56.92\% vs. $43.08 \%$ ), Khan, et al. ${ }^{7}$ from Lahore, Pakistan $(68.15 \%$ vs. $31.85 \%)$, Mousawea , et al. ${ }^{6}(79.01 \%$ vs. $20.99 \%)$, Tao, et al. ${ }^{5}(58.53 \%$ vs. $41.47 \%)$, Soliman, et al. ${ }^{4}(67.25 \%$ vs. $32.75 \%)$ \& Badawi, et al. ${ }^{3}(77.81 \%$ vs. $22.19 \%)$. Dissimilar to our findings, lower prevalence in men than women were delineated by Ullah, et al. ${ }^{8}$ from Peshawar, Pakistan (38.46\% vs. $61.54 \%$ ). No study describing similar prevalence in men and women could be sorted out from literature.

Our observed prevalence of hepatitis B infection in men $70.52 \%$ was higher than its expected (adjusted) prevalence for men $56.92 \%$ \& in women $29.48 \%$ it was lower than its expected (adjusted) prevalence for women $43.08 \%$ as shown by Khan, et al. ${ }^{9}$ (Table 3.2.1.2)

4.2 Distribution of hepatitis $B$ infected population by age groups $\left(\mathbf{H}_{02}\right)$ : In our study hepatitis $B$ infection was most common in age group 21-40 years $53.46 \%(95 \% \mathrm{Cl} 51.45-55.46)$, followed by $0-20$ years $23.73 \%$ (95\% Cl 22.06-25.29), $41--60$ years $19.51 \%$ $(95 \% \mathrm{Cl} 17.96-21.15) \quad \&>60$ years $3.30 \%(95 \% \mathrm{Cl}$ 
2.65-4.10). (Table 3.1.1)

In a study by Badawi, et al. ${ }^{3}$ PCR detected HBV infection was most common in age group 20-39 years $64.06 \%$,followed by $40-59$ years $24.56 \%,<20$ years $6.16 \%, 60-79$ years $4.93 \% \&>80$ years $0.29 \%$. In a study by Tao, et al. ${ }^{5}$ PCR detected HBV infection was most common in age group $20-49$ years $77.82 \%$, followed by $\geq 50$ years $20.26 \%, 6-19$ years $1.56 \%,<1$ years $0.27 \% \& 1-5$ years $0.09 \%$.

In a study by Mousawea, et al. ${ }^{6} \mathrm{HBsAg}$ positive patients were most common in age group 21-40 years $49.79 \%$, followed by $41-60$ years $30.91 \%, \geq 61$ years $10.62 \% \& 1-20$ years $8.68 \%$.

In a study by Ullah, et al. ${ }^{8}$ from Peshawar, Pakistan, $\mathrm{HBsAg}$ positive patients were most common in age group $41-60$ years $50 \%$, followed by $21-40$ years $24.19 \%, 61-80$ years $24.19 \%$ \& $1-20$ years $1.61 \%$.

As reported by Khan, et al. ${ }^{9}$ from Mardan, Pakistan, PCR detected HBV infection was most common in age group $21-40$ years $60.38 \%$, followed by $41-60$ years $19.62 \%, 1-20$ years $11.54 \% \&>60$ years $8.46 \%$. In a study by Ullah, et al. ${ }^{10}$ from Mardan, Pakistan, PCR detected HBV infection was most common in age groups $21-40$ years $78.26 \%$, followed by $41-60$ years $16.67 \%, 10-20$ years $3.62 \% \& \geq 61$ years $1.45 \%$. Our observed prevalence of hepatitis B infected population in the four age groups was different from what we expected for the four age groups from a study by Khan, et al. ${ }^{9}$ from Mardan, Pakistan. (Table 3.2.2.2)

4.3 Marwat Logical Trajectory of Research Process: We have incorporated the innovated model of "Marwat Logical Trajectory of Research Process" in our project. ${ }^{16-19}$

\section{CONCLUSION}

In our study, hepatitis B infection was more common in men than women and most common in age group 21-40 years, followed by 0-20 years, 41-60 years and $>60$ years. Our observed prevalence of hepatitis $B$ infection in men was higher than expected \& in women it was lower than expected. Our observed prevalence in the four age groups was not similar to expected.

Acknowledgement: Dr. Muhammad Marwat from Gomal Medical College, D.I.Khan is highly acknowledged to give us permission to use his "Marwat Logical Trajectory of Research Process" for ours this project.

\section{REFERENCES}

1. Key data at a glance. In: Global progress report on HIV, viral hepatitis and sexually transmitted infections, 2021. Accountability for the global health sector strategies 2016-2021: actions for impact [accessed 2021 Feb 13]. Geneva: World Health Organization; 2021. Available at: http:// apps.who.int/iris/
2. Global Hepatitis Report 2017 [accessed $2021 \mathrm{Feb}$ 13]. Geneva: World Health Organization; 2017. Available at: http://apps.who.int/iris/

3. Badawi MM, Mohammed AA, Mohammed MS, Saeed MM, Ali EY, Khalil A. A diagnostic laboratory-based study on frequency and distribution of viral hepatitis $B$ and $C$ among Sudanese. Open Virol J 2017 Oct 31; 11:98-107. https://doi.org/1 $0.2174 / 1874357901711010098$

4. Soliman G, Elzalabany MS, Hassanein T, Miller FD. Mass screening for hepatitis $B$ and $C$ in Southern Upper Egypt. BMC Public Health 2019 Oct 22; 19(1):1326. https://doi.org/10.1186/ s12889-019-7640-1

5. Tao J, Zhang W, Yue H, Zhu G, Wu W, Gong W, et al. Prevalence of hepatitis $B$ virus infection in Shenzhen, China, 2015-2018. Sci Rep 2019 Sep 26; 9(1):13948. https://doi.org/10.1038/s41598019-50173-5

6. Mousawee SM, Moossavi M, Bahrami A, Rasekh $H$, Naghizadeh MS, Abd H, Fereidouni M. The prevalence of hepatitis $\mathrm{B}$, hepatitis $\mathrm{C}$ and human immunodeficiency viral infections among a large population of Afghans. Hepat Mon 2020 Jul 31; 20(7). https://doi.org/10.5812/hepatmon.101012

7. Khan F, Shams S, Qureshi ID, Israr M, Khan H, Sarwar MT. Hepatitis B virus infection among different sex and age groups in Pakistani Punjab. Virol J 2011 May 13; 8:225. https://doi. org/10.1186/1743-422X-8-225

8. Ullah Q, Khan K, Saeed K. Prevalence of hepatitis $C$ and $B$ in MURCY Hospital Peshawar, KP, Pakistan. J Entomol Zoo Studies 2017:1081-4.

9. Khan MA, Waqar M, Rehman Z, Idrees M, Wasim M, Asghar A, et al. Hepatitis B virus (HBV) a severe health problem in Mardan, Khyber Pakhtunkhwa: A molecular based study. Bio Sci Rev 2019 Feb 14;1(1):25-32. https://doi.org/10.32350/ BSR.0101.03

10. Ullah N, Khan I, Kakakhel MA, Xi L, Bai Y, Kalra BS, et al. Serological prevalence of hepatitis $B$ virus (HBV) in Mardan district, Khyber Pakhtunkhwa, Pakistan. Braz J Biol 2021 Jul 14; 82:e245813. https://doi.org/10.1590/1519-6984.245813

11. Raosoft $\AA$ sample size calculator [internet]. Seattle, WA, USA: Raosoft Inc.; 2004. [accessed 2021 Feb 13]. Available at: http://www. raosoft. com/samplesize.html

12. Statistics Kingdom. Proportion confidence interval calculator [internet]. Statistics Kingdom; Melbourne, Australia 2007. [accessed 2021 Feb 13]. Available at: http://www.statskingdom. com/41_proportion_confidence_interval.html

13. Zar JH. Biostatistical Analysis. 5th ed. New York: Prentice-Hall, Inc.

14. Daniel WW. Biostatistics: A Foundation for Analysis in the Health Sciences. 7th ed. Singapore: John Wily; 2005.

15. Social Science Statistics. Statistical Tests Calculators [Internet]. [accessed 2021 Feb 13]. Available at: https://www.socscistatistics.com/ tests/goodnessoffit/default2.aspx 
16. Ghori MR, Khan H, Marwat M. Distribution of non-malignant hematological disorders by sex, age groups and type of disease based on bone marrow aspiration in population of Khyber Pakhtunkhwa, Pakistan. Gomal J Med Sci 2019 Apr-Jun; 17(2):29-36. https://doi.org/10.46903/ gjms/17.02.1926

17. Ain N, Khan S, Marwat M, Khan N, Ahmad I, Ramzan F, et al. Frequency, distribution and determinants of hypertension in adult stroke population of D.I.Khan Division, Pakistan. Gomal J Med Sci 2019 Jul-Sep;17(3):81-9. https://doi. org/10.46903/gjms/17.03.2076
18. Akhtar A, Ali SM, Naqi SA, Aziz T, Shinwari W, Shah SFH. Efficacy of acetic acid versus ciprofloxacin ear drops in achieving dry ears in chronic suppurative otitis media in adult population of Islamabad, Pakistan: a non-randomized control trial. Gomal J Med Sci 2019 Jul-Sep;17(3):90-4. https://doi.org/10.46903/gjms/17.03.2007

19. Marwat M, Ahmad I, Ashiq F, Ali S, Zamir S, Rehman MU, et al. Frequency, distribution and determinants of diabetes mellitus in adult acute coronary syndrome population of D.I.Khan Division, Pakistan. Gomal J Med Sci 2019 OctDec;17(4):131-43. https://doi.org/10.46903/ gjms/17.04.2106

\section{CONFLICT OF INTEREST \\ Authors declare no conflict of interest. GRANT SUPPORT AND FINANCIAL DISCLOSURE None declared.}

\section{AUTHORS' CONTRIBUTION}

The following authors have made substantial contributions to the manuscript as under:

$$
\text { Conception or Design: IU, NK }
$$

Acquisition, Analysis or Interpretation of Data: $\quad$ IU, NK, FS, EA, AS

Manuscript Writing \& Approval:

IU, NK, FS, EA, AS

All the authors agree to be accountable for all aspects of the work in ensuring that questions related to the accuracy or integrity of any part of the work are appropriately investigated and resolved. 